\title{
STEM CELLS NEWS UPDATE: A PERSONAL PERSPECTIVE
}

\author{
Wong SC*
}

*Corresponding Author: Shiu C. Wong, Ph.D., M.B.A., Stem Cell Link, Hong Lok Building, Block M, $1^{\text {st }}$ Floor, 96 Chik Fuk Street, Tai Wai, New Territories, Hong Kong, Special Administration Region, People's Republic of China; Tel.: +852-677-22933; E-mail: scwong555@gmail.com

\begin{abstract}
This article is a follow-up to a previous Commentary published in 2011. It updates some of the events mentioned in that Commentary and continues with more interesting and exciting news on stem cell research and the emerging field of Regenerative Medicine. Some of the news includes: 1) the 2012 Nobel Prize for Medicine awarded to John B. Gurdon and Shinya Yamanaka; 2) the cloning of human embryonic stem cells; 3) the continued search for truly pluripotent adult stem cells via in vitro and in vivo protocols; 4) the breakthrough in organ replacements; 5) the global stem cell race; 6) the global stem cell cryo-preservation business; 7) the worldwide stem cell donor registries, and $\boldsymbol{8}$ ) the issue of government regulation on stem cell therapy.

Keywords: Pluripotent stem cells; Organ replacement; Stem Cell Registry.
\end{abstract}

\section{INTRODUCTION}

This article is a follow-up to my Commentary published in this Journal 2 years ago [1], and is dedicated to the memory of Professor Dr. Georgi D. Efremov (founder and first Editor-in-Chief of BJMG) and Professor Dr. Titus H.J. Huisman (founder and first Editor-in-Chief of Hemoglobin).

Stem Cell Link, Tai Wai, New Territories, Hong Kong, Special Administration Region, People's Republic of China
It will put closure to some of the events mentioned in the previous Commentary, and then continue with news and websites concerning some of the recent developments in the emerging field of Regenerative Medicine.

What Has Happened Since 2011. In my 2011 Commentary, I quoted the 'parallel' between IVF (in vitro ferti-lization) and stem cells, and cited the award of the 2010 Nobel Prize for Medicine to Professor Robert Geoffrey Edwards for his pioneering work in human IVF. There are two updates. First and sadly, it is heart-breaking to report that Professor Edwards died on Wednesday, April 10 2013, at the age of 87 [2]. Second, on a happier note, for their work on stem cells and the discovery of iPSC (induced pluripotent stem cells), Professor John B. Gurdon and Professor Shinya Yamanaka were awarded the 2012 Nobel Prize for Medicine [3].

For the past decade, the continuing argument on the legality of US Federal funding for human embryonic stem cells (hESC) research as well as the court petition Sherley vs. Sebelius (12-454) [viz. James L. Sherley and Theresa Deisher (two stem cell scientists) vs. Kathleen Sebelius (Secretary, Department of Health \& Human Services, NIH)] came to a closure earlier this year. On January 102013 , the US Supreme Court, to the delight of many, put an end to this legal 'saga' once for all, by refusing to hear the case [4].

In the meantime, there have been bad news and good news concerning the first two Food and Drug Administration (FDA)-approved clinical trials. First 
the bad news: on November 4 2011, the Californiabased Geron's clinical trial of a hESC-based therapy for spinal cord injury was halted citing financial reasons. Luckily, earlier this year (on January 72013 ), the California-based BioTime announced that they would buy all Geron's hESC assets [5]. I look forward to better news from BioTime.

Unlike Geron, the Advanced Cell Technology (ACT) macular dystrophy project has nothing but good news. A preliminary January 232012 report in Lancet [6] described improved vision of two California women, 4 months after the injection of 50,000 of hESC-derived retinal pigment epithelial (RPE) cells under the retina. Since then, most of the other 22 similarly treated patients also had improvements in vision. I cannot wait for more good news from ACT.

Besides the Geron and ACT clinical trials, the first UK phase I clinical trial of a neural stem cell therapy using ReNeuron's ReN001 for stroke patients also had good news, viz. mild to moderate improvements were observed in five of the nine longterm stroke patients [7]. Thus, the PISCES trial in the UK looks promising as well.

Regarding the 'law enforcement' story, first broadcast in April 2010 in the American television program "60 Minutes" and included in my 2011 Commentary [1], there should be closure soon. In January 2012, the FBI (Federal Bureau of Investigation) arrested three of the individuals who preyed on the sick with 'miracle stem cell cure', and was going after the fourth man [8]. In the meantime, the crackdown on this kind of unscrupulous individuals continues. For example, a Bonita Springs cardiologist, Zannos Grekos, has recently been (March 2013) prosecuted for "unorthodox stem cell therapy in 2010 on 69-year-old Domenica Fitzgerald" who died on April 4, 2010 [9].

The above section of this article updates some of the events that have been referred to in my 2011 Commentary [1]. The following sections will highlight more recent news on stem cells. I will start with two pieces of 'news with a twist': 1) the 2012 Nobel Prize, and 2) the May 2013 article in Cell on the successful cloning of human embryonic stem cells.

The 2012 Nobel Prize and the Lawsuit. Only a few months after the award of the 2012 Nobel Prize for Medicine to John B. Gurdon and Shinya Yamanaka, a California surgeon Rongxiang $\mathrm{Xu}$ filed a lawsuit "suing the Nobel Assembly for failing to recognize him for his work on regenerative medicine," and a separate lawsuit against both the Nobel Laureates [10,11].

It is surely sad to read such news, especially as it involves a lawsuit, the first of its kind, against the Medical Nobel Assembly at the Karolinska Institute in Sweden. However, it reminds me of a similar lament by Bruno Lemaitre towards Jules Hoffman (one of the 2011 Nobel Prize winners) on Lemaitre's contribution to the discovery of the "Toll and Imd pathways in Drosophila immunity" [12]. After Lemaitre's lament, a satiric question was raised: "A Nobel Prize not Immune from Error?" [13].

Article Regarding Nuclear Transfer-Human Embryonic Stem Cells/“A A New Kind of Stem Cell". Cell published the cloning of human embryonic stem cells by Dr. Shoukhrat Mitalipov (Tachibana et al., [14]) in Portland, OR, USA using the technique of somatic cell nuclear transfer (SCNT) previously used for the cloning of Dolly The Sheep in 1996. The newly discovered NThESC (nuclear transfer-human embryonic stem cell) was immediately hailed as the "new stem cells on the block" and as "a tour de force and an unparalleled achievement". However, only a few days after its publication, these findings were over-shadowed by an anonymous comment in Pubpeer. com questioning problems in the paper [15]. A follow-up in Nature News by Cyranoski [16] reported that Dr. Shoukhrat Mitalipov indeed acknowledged errors in his paper, but insisted that "The results are real, the cell lines are real, everything is real."

Personally, I hope that the errors in the Tachibana et al. [14] article could be amended and the scientific findings confirmed as soon as possible. I surely hope that, in the near future, I do not have to read any more follow-up news on the NT-hESC story similar to the news on the "Rise and Fall" of Woo Suk Hwang, the Korean stem cell researcher [17].

Searching for Truly Pluripotent Adult Stem Cells. Having mentioned Dr. Yamanaka's iPSC and Dr. Tachi-bana's NT-eESC above, I would like to report briefly three recent findings on the search for sources of the truly pluripotent adult stem cells, viz. 1) kidney cells in urine, 2) breast tissue and 3) adipose tissue. First, regarding urine as a source, it was Dr. Duangqing Pei's team of researchers in Guangzhou, People's Republic of China (PRC) [Zhou et al., 
18] who in 2011, reported the successful reprogramming of kidney epithelial cells harvested from urine into human iPSCs that could then turn into neural progenitor cells. Commenting on urine being a possible source for pluripotent adult stem cells, Dr. Marc Lelande, a geneticist at the University of Connecticut Health Center, said: "We work on childhood disorders, and it's easier to get a child to give a urine sample than to prick them for blood." Very true indeed!

Second, regarding breast tissues as a source, it was Dr. Thea Tlsty of University of California, San Francisco (UCSF), CA, USA, who in 2013, reported her discovery of a rare population of stem cells collected from human breast tissue of healthy adults. She named these adult stem cells 'endogenous pluripotent stem cells' (ePSC) that could be reprogrammed to beating heart cells [Roy et al., 19].

Third, regarding adipose tissue as a source, it was Dr. Gregorio Chazenbalk who in 2013, reported the discovery of 'Muse-AT cells', i.e., multilineagedifferentiating stress-enduring cells, derived from adipose tissue [Heneidi et al., 20]. These Muse-AT cells were able to differentiate into mesenchymal, endodermal and ectodermal cells, viz. adipocytes, hepatocytes and neural cells. The finding of 'truly pluripotent adult stem cells' from body fat, easily obtainable via liposuction, was hailed as "something of a holy grail for an abundant, cheap and easy-to-obtain source of stem cells."PAGE

The above-described three potential sources of truly pluripotent adult stem cells, if proven to be the case, will surely be important assets in the practice of Regenerative Medicine. I cannot wait to hear more positive results from Guangzhou, PRC, San Francisco and Los Angeles, CA, USA. On a lighter note, the 'fat' story bears a similar ring to the 'urine' story, i.e., it may turn out that two possible ideal sources of truly pluripotent adult stem cells are two things in our body that, when in excess, we are happy to get rid of!

Reprogramming In Vivo/Embryonic Stem Cells Created in Living Mice. The above-described iPSCs from urine, breast tissue and adipose tissue are created via in vitro reprogramming of the adult human cell sources in laboratories. In a recent article in Nature, Professor Manuel Serrano and Dr. Maria Abad of Spain reported the recovery of iPSC via in vivo reprogramming in life animal [Abad et al., 21]. Induction of embryonic-state stem cells in bio-engineered mice was successfully carried out with the insertion of extra copies of Oct4, Sox2, Klf4 and c-Mycin genes that were then switched on by feeding the mice with the antibiotic doxycycline. These iPSCs from in vivo reprogramming have characteristics of embryonic stem cells and even have totipotent properties equivalent to those observed in 16-cell human embryos. I look forward to hearing news concerning clinical applications of this in vivo reprogramming protocol, and hope that regeneration of specific cell types within our own bodies can soon be achieved to replace damaged organs in the near future.

Holy Grail of Regenerative Medicine. It is the general consensus that the 'Holy Grail' of stem cell research is the creation of whole working organs for transplant. The search for 'replacement parts', viz. whole working organs of $\boldsymbol{a}$ ) bladder, $\boldsymbol{b}$ ) heart and c) trachea was chronicled by Yong [22]. In 2006, Professor Anthony Atala and colleagues [23] of Wake Forest Institute for Regenerative Medicine (Winston-Salem, NC) successfully implanted seven patients with auto-logous-engineered bladder constructs on scaffolds made of a composite of collagen and polyglycolic acid. It was hailed as 'a milestone' in the science of growing organs. Another 'milestone' came in 2008, when Dr. Harald Ott of the Massachusetts General Hospital (Boston, MA), and Dr. Doris Taylor of the University of Minnesota (Minneapolis, MN) reported their results of using decellularized cadaveric rat hearts as scaffolds for engineering bioarti-ficial hearts [Ott et al., 24]. Three years later, it was reported that Dr. Taylor succeeded in carrying out 'whole organ decellularization' of human cadaveric hearts and reseeding the ghost hearts, i.e., the scaffolds, with human adult stem cells to produce regenerated hearts in her laboratory [25]. Back in the same year of 2008, the landmark trachea replacement was achieved by pioneering surgeon Professor Paolo Macchi-arini (Barcelona, Spain and his professional collaborators [26], who successfully transplanted the first tissueengineered trachea to 30-year-old Claudia Castillo in Barcelona. As of July 2013, Professor Macchiarini and his colleagues have carried out 15 trachea operations using the patients' own stem cells seeded onto man-made scaffolds or cadaveric scaffolds.

Two of Professor Macchiarini's 15 trachea-patients were children, viz. 11-year old Ciaran Finn- 
Lynch and 2-year old Hannah Warren. In March 2010, Ciaran Finn-Lynch (born with Long Segment Tracheal Stenosis) became the first 11-year old boy whose own body was used as a 'bioreactor' (because of the urgency in this case) where his own stem cells, seeded on a donated trachea-scaffold, were allowed to repopulate and grow [27]. Professor Macchiarini and Professor Martin Birchall of University College London, London, UK, performed this 'historic' trachea operation at the Great Ormond Street Hospital for Children in London, UK. Two years after the operation, Ciaran was 11 $\mathrm{cm}$ taller and his windpipe had also grown with him inside his body. Dr. Harald Ott commented that "the holy grail of tissue engineering is to come up with something that is so integrated into the human body that it grows with the human body." The story of Ciaran is certainly amazing.

On the other hand, the story of Hannah Warren, the youngest-ever 'trachea transplant' patient, does not have such a happy ending. However, her story is surely an inspirational one. Hannah, a 2-year-old Korean-Canadian, was born without a trachea (i.e., Tracheal Agenesis) and had been kept alive with a substituted windpipe. Dr. Mark Holterman of the Children's Hospital of Illinois in Peoria, IL, USA, helped to bring Hannah from Korea to the United States. In April 2013, Professor Macchiarini from Stockholm led the surgical team in a 9-hour operation of transplanting an artificial trachea into Hannah (of a plastic-fiber-scaffold) seeded with her own bone marrow cells [28]. After this historic trachea operation, Hannah's father, Darryl Warren, exclaimed "We feel like she's reborn." However, it was heart-breaking to learn that 3 months after the ground-breaking windpipe transplant, Hannah died on July 6 as a result of "additional health issues." The statement by the Children's Hospital of Illinois declared that "we take comfort in the knowledge that the efforts of her physicians and the care team working with them will benefit and serve other children and adults in the years to come." Well said indeed!

Expansion and Rapid Establishment of Stem Cell Centers Around the World. In the US, after President Bush's 2001 executive order limiting federal funding for hESC research, some states took the matter of 'stem cell funding' into their own hands. This started with California, where Californians passed the Proposition 71, i.e., the California
Stem Cell Research and Cures Act in 2004, to establish the California Institute for Regenerative Medicine (CIRM) with a $\$ 3$ billion budget earmarked for 10 years. More recently, in July 2013, the CIRM governing board has approved a \$70-million plan to establish the Alpha Stem Cell Clinics Network between academic institutions in the State for conducting clinical trials of stem cells [29].

After California, other states in the US have followed suit. These include Maryland with the passing of the Maryland Stem Cell Research Act to establish the Maryland Stem Cell Research Fund (MSCRF) [30]; Texas with the Cancer Prevention and Research Institute of Texas (CPRIT), Austin, TX which was earmarked in 2011 with a \$3 billion research fund for 10 years [31]; Kansas with a new Stem Cell Center at the University of Kansas, Kansas City, KS starting in July 2013 [32] and New York with a new Upstate Stem Cell cGMP Facility Stem Cell Research Center at the University of Rochester, New York, NY [33].

While new centers are being set up to get into the 'stem cell boom', well-established centers are expanding at a tremendous rate to lead the 'stem cell race.' In 2011, the Roddenbury Foundation, for decades the benefactor of the Gladstone Institute in California, announced the creation of a new Roddenberry Center for Stem Cell Biology and Medicine by the UCSF's Mission Bay campus. Also in 2011, the Sanford Consortium for Regenerative Medicine was set up in a 132,000 square-foot building off La Jolla in San Diego, CA, with joint interest and partnership with five academic institutions in southern California. Thus, it was no surprise that San Diego would be hosting the 9th Annual World Stem Cell Summit in December 2013 [34].

At the same time, other countries around the world are pushing ahead in the emerging field of Regenerative Medicine. In Scotland, the $\$ 85$ million Scottish Centre for Regenerative Medicine (SCRM) and the $\$ 38$ million bio-incubator facility at Edinburgh (Scotland, UK) were established within the last 2 years. More recently, in March 2013, Welsh Economy Minister Edwina Hart announced the endowment of $£ 100$ million in the Life Science Investment Fund, part of which was to attract bio-medical companies to relocate to Wales. One of the companies was the famous Sir Chris Evans' ReNeuron, involved in the UK PISCES clinical trial. Sir Chris is 
also Chairman of the Wales Life Science Investment Fund and former Chairman of BioMalta in Malta.

Interestingly, because of his various personal involvements in the stem cell businesses, Sir Chris is making news lately (albeit not all good). First, a recent Business Weekly news reported that Sir Chris was being investigated by the Wales Audit Office for irregularity of investing public funds [35]. Second, Sir Chris' role as special envoy on biotechnology was terminated by Malta Enterprise, and Sir Chris' demand for an apology from Malta Prime Minister Joseph Muscat was flatly denied [36]. Thus, one needs to do one's homework when investing in biotechnology ventures!

Brief Update on Umbilical Cord Blood Stem Cell Banks. Currently, there are more than 100 public and 130 private cord blood banks, with a total of 1.5 million units of cord blood stored. It is estimated that over 30,000 umbilical cord blood transplantations (UCBT) have been carried out since the first UCBT performed by Dr. E. Gluckman and Dr. H.E. Broxmeyer (the pioneers in Umbilical Cord Blood Transplantation \& Banking) 25 years ago in 1988. On the subject of stem cell transplantation, we owe everything to the vision of the late Professor Dr. E. Donnall Thomas, who carried out the first bone marrow stem cell transplant in 1957 and received the Nobel Prize in 1990. It was in December 2012 last year that the 1 millionth blood stem cell transplant was carried out, marking a major medical milestone in the history of modern medicine.

Stem Cell Donor Registry, Adult Peripheral Blood Stem Cell Banking and Adult Induced Stem Cell Banking. Nowadays, there are worldwide stem cell registries, viz. Anthony Nolan Registry (Scotland), National Marrow Donor Program (USA), Be The Match Registry (USA), OneMatch Stem Cell \& Marrow Network (Canada), China Marrow Donor Program (China), South Africa Bone Marrow Registry (South Africa) and others. Their coordinating efforts have resulted in many successful stem cell donations. For example, a 24-year-old Navy Seabee donated his peripheral blood stem cells (PBSC) to save the life of someone with a fatal blood disease [37]. Another success story concerns Robin Roberts, the popular co-anchor of the US television program "Good Morning America," who was diagnosed to have myelodysplastic syndrome. Six months after a bone marrow stem cell transplant from her older sister Sally-Ann, Robin returned in February 2013 to host the \#1-rated US morning show [38].

Regarding PBSC banking, I support the Letter published in Lancet [39] that five Japanese medical scientists proposed to the Japanese Government (after the March 112011 earthquake and tsunami) to harvest and cryo-preserve autologous PBSC from workers at the damaged Fukushima Daiichi nuclear power plant as soon as possible. I am not sure what has been done after the above April 30 2011 'PBSC-Proposal'. I just hope that Tepco (the Operator of the Fukushima nuclear plant), with the recent (September 2013) allocation of almost half a billion dollars from the Japanese Government, will take prompt actions to contain the leakages at the Fukushima plant and to safeguard the well-being of the workers.

In the mean time, besides Umbilical Cord Blood Banking and PSBC Banking (which are indeed worthwhile insurance for one's future good health), there is a 'new kid on-the-block'. Recently, Cellectis, a French genome technology company, has launched an 'Adult iPSC Banking' service, which (for now) is meant only for the rich-n-famous. For US\$60,000 (around £40,000), Cellectis will reprogram the client's adult skin cells to iPSCs via Yama-naka's Nobel-Prize-winning recipe, and will cryo-preserve the iPSCs at $-180^{\circ} \mathrm{C}$ in the Cellectis' laboratories located in the UK, Switzerland, Singapore, USA and Dubai [40].

\section{SUMMARY REMARKS}

From the news reports in the past 2 years, we learn that the search for the Holy Grail of Regeneration Medicine, i.e., the creation of whole working organs, is moving forward at full speed. What medical scientists have been able to achieve with decellularized 'scaffolds' and 'spray-on' stem cells is amazing. Moreover, the recent Nature "Reprogramming in vivo" article from Spain ]21[ may indeed have a strong impact on 'organ replacement' soon.

Similar to my 2011 Commentary [1], I wish to conclude this article with a few words on the issue of 'government laws and regulations.' It is true that there are still countries that need to impose better regulation on unproven stem cell treatments carried out by unscrupulous individuals. Fortunately, there are countries in which their government agencies 
are working hard to establish laws and restrictions to regulate such unproven stem cell therapies. First, the US is an example. In 2008, the US Food and Drug Administration (FDA) began investigating Regenerative Sciences Inc. in Broomfield, $\mathrm{CO}$ for treating orthopedic problems using the company's stem cell product called 'Regenexx' [41]. In July 2012, after 4 years of investigation and legal argument (United States of America vs. Regenerative Sciences), a US Federal Court ruled that the 'stem cell culture product is a drug,' since the stem cells extracted from the patient's own bone marrow were more than minimally manipulated using reagents that were transported across state lines [42].

As mentioned in my 2011 Commentary [1], the stem cell businesses in China were described as 'Stem Cell China. Wild East or Scientific Feast.' It sounded good that in January 2012, the Chinese Ministry of Health announced "All medical research and clinical practices of stem cell therapy without approval from the ministry and the State Food and Drug Administration will be put to an end after the overhaul." However, this 2012 Health Ministry announcement has fallen on deaf ears. It was thus reassuring that in March 2013, the Chinese Ministry of Health (MOH) and the State Food and Drug Administration (SFDA) issued a joint announcement, detailing the draft regulations and requirements for drug and stem cell clinical trials and indicating non compliant centers would face severe penalties [43]. At this time, 1 can report that the Chinese $\mathrm{MOH}$ and SFDA's crackdown on unapproved stem cell centers seems to be working. I have learned that a few stem cell centers have indeed completely stopped their operations in China since the early part of 2013.

The above regulatory news from the US and China is encouraging. However, a word of caution is worth repeating. In view of the increasing interest in 'stem cell tourism' and the huge profits from marketing 'stem cell therapy,' I suppose unproven stem cell therapies will continue in countries where regulations are less stringent. I sincerely hope that I do not have to hear more news about patients who have died from such unproven treatments!

Finally, I wish to end this article on a high note with one more inspirational story. A recent Los Angeles television news and video in August 2013, reported the happy and emotional first-time meeting between a Stem Cell Donor (a young German woman living in Dresden, Germany) and a Stem Cell Recipient (an American woman living in Orange County, CA) 2 years after the PBSC from the former had saved the latter from leukemia [44]. I sincerely hope that stories like this will inspire more individuals to register as stem cell donors to "Save A Life Someday!"

\section{ACKNOWLEDGMENTS}

The author would like to thank $\boldsymbol{a}$ ) Professor Man-Chiu Poon (University of Calgary, Calgary, AB, Canada) and Dr. David Y.L. Lai (US Environmental Protection Agency, Washington, DC, USA) for their critical review of the manuscript; $\boldsymbol{b})$ Dr. Paul K.T. Pang (Glendale, CA, USA) for referring and bringing the author's attention to some of the news items discussed in this Commentary, and $\boldsymbol{c}$ ) Mrs. Ann P. Patch and Mrs. Marianne M.F. Carver [Titus H.J. Huisman Comprehensive Sickle Cell Center, Georgia Regents University (formerly the Medical College of Georgia) Augusta, GA, USA) for their friendship and continuing support throughout all these years since 1969 .

Declaration of Interest. The author reports no conflicts of interest. The author alone is responsible for the content and writing of this article.

\section{REFERENCES}

1. Wong SC. Stem cells: a personal perspective. Balkan J Med Genet. 2011; 14(2): 7-11.

2. Kelland K. British "test tube baby" pioneer Robert Edwards dies. Reuters, April 102013. [http://www.reuters.com/article/2013/04/10/ us-ivf-edwards-idUSBRE9390IE20130410?fe edType $=$ nl\&feedName $=$ usmorningdigest. $]$

3. Mole BM. Cell re-programmers Take the Nobel. The Scientist, October 8 2012. [http:// www.the-scientist.com/?articles.view/articleNo/32765/title/Cell-Re-Programmers-Takethe-Nobel/.]

4. Editorial. Stem cell research gets a reprieve. New York Times, January 21 2013. [http:// www.nytimes.com/2013/01/21/opinion/embryonic-stem-cell-research-gets-a-reprieve. html.] 
5. Mole BM. Geron sells stem cell assets. The Scientist, January 8 2013. [http:www.thescientist.com/?articles.view/articleNo/33876/ title/Geron-Sells-Stem-Assets/.]

6. Schwartz SD, Hubschman J-P, Heilwell G, Franco-Cardenas V, Pan CK, Ostrick RM, et al. Embryonic stem cell trials for macular degeneration: a preliminary report. Lancet. 2012; 379(9817): 713-720.

7. Cossins D. Stroke patients improve with stem cells. Long-term stroke patients involved in a small-scale clinical trial of a neural stem-cell therapy show signs of recovery. The Scientist, May 28 2013. [http://www.the-scientist. com/?articles.view/articleNo/35748/title/ Stroke-Patients-Improve-with-Stem-Cells/.]

8. Forsyth J. Three arrested for peddling miracle stem cell cure. Reuters News, January 22012. [http://www.reuters.com/article/2012/01/02/usstem-cell-arrest-idUSTRE8010RP20120102.]

9. Freeman L. State judge: Bonita stem cell doctor Grekos should lose medical license. [http:// www.naplesnews.com/news $/ 2013 / \mathrm{mar} / 11 /$ state-judge-bonita-springs-stem-cell-doctorgrekos/.]

10. Maxmen A. Snubbed for a Nobel? A surgeon sues the Nobel Assembly for excluding him from last year's prize awarded for regenerative medicine. The Scientist, March 142013. [http:/www.the-scientist.com/?articles. view/ articleNo/34705/title/Snubbed-for-a-Nobel-/.]

11. Yandel K. Suing over a Nobel. The scientist who sued the Nobel committee is now suing Nobel winner Shinya Yamanaka. The Scientist, May 16 2013. [http://www.the-scientist.com//? articles.view/articleNo/35582/title/SuingOver-a-Nobel/.]

12. Lemaitre B. Toll and Imd pathways in Drosophila immunity. December 4 2011. [http:// www.behinddiscoveries.com/toll/mixedfeelings.]

13. Garwood J. A Nobel prize not immune from error? Lab Times Online, December 122011. [http://www.labtimes.org/editorials/e_270.lasso.]

14. Tachibana M, Amato P, Sparman M, Gutierrez NM, Tippner-Hedges R, Ma H, et al. Human embryonic stem cells derived by somatic cell nuclear transfer. Cell. 2013; 153(6): 1228-1238.

15. [pubpeer.com/publications/23683578.]

16. Cyranoski D, Hayden EC. Stem-cell cloner acknowledges errors in groundbreaking paper. Critics raise questions about rush to publication. Nature, May 23 2013. [http://www.nature. com/news/stem-cell-cloner-acknowledges-errors-in-groundbreaking-paper-1.13060.]

17. Cyranoski D. Rise and fall. Why did Hwang fake his data, how did he get away with it, and how was the fraud found out? Nature, January 11 2006. [http://www. nature. com/ news/2006/060109/full/news060109-8.html.]

18. Zhou T, Benda C, Duzinger S, Huang Y, Li X, $\mathrm{Li} \mathrm{Y}$, et al. Generation of induced pluripotent stem cells from uine. J Am Soc Nephrol. 2011: 22(7): 1221-1228. [http:// jasn.asnjournals.org/ content/22/7/1221.]

19. Roy S, Gascard P, Dumont N, Zhao J, Pan D, Petrie S, et al. Rare somatic cells from human breast tissue exhibit extensive lineage plasticity. Proc Natl Acad Sci USA. 2013; 110(12): 4598-4603. [http://www.pnas.org/ content/110/12/4598.]

20. Heneidi S, Simerman AA, Keller E, Singh P, Li X, Dumesic DA, et al. Awakened by cellular stress: isolation and characterization of a novel population of pluripotent stem cells derived from human adipose tissue. PLoS One. 2013; 8(6): e64752. doi:10.1371/journal. pone.0064752. Print2013.

21. Abad M, Mosteiro L, Pantoja C, Cañamero M, Rayon T, Ors I, et al. Reprogramming in vivo produces teratomas and iPS cells with totipotency features. Nature. 2013; 502(7471): 340-345.

22. Yong E. Replacement parts. To cope with a growing shortage of hearts, livers, lungs suitable for transplant, some scientists are genetically engineering pigs, while others are growing organ in the lab. The Scientist, August 12012. [http:www.the-scientist.com/?articles.view/article No/32409/title/Replacement-Parts/.]

23. Atala A, Bauer SB, Soker S, Yoo JJ, Retik AB. Tissue-engineered autologous bladders for patients needing cystoplasty. Lancet. 2006; 357(9518): 1241-1246. 
24. Ott HC, Matthiesen TS, Goh S-K, Black LD, Kren SM, Netoff TI, et al. Perfusion-decellularized matrix: using nature's platform to engineer a bioartificial heart. Nat Med. 2008; 14(2): 213-221.

25. Leake J. Human hearts created in lab. Medical scientists ae growing the first living human hearts to be created in a laboratory. The Sunday Times, April 3 2011. [http://www. theaustralian.com.au/news/health-science/ human-hearts-created-in-1ab/story-e6frg8y6-1226032807148.]

26. Macchiarini P, Jungebluth $P$, Go T, Asnaghi MA, Rees LE, Cogan TA, et al. Clinical transplantation of a tissue-engineered airway. Lancet. 2008; 372(9655): 2023-2030.

27. Gallager J. Ground-breaking windpipe-transplant child "doing well". BBC, July 262012. [http://www.bbc.co.uk/news/health-18980915.]

28. Girl gets stem cell windpipe in historic operation. "We feel like she's reborn," says father, who is originally from Newfoundland. The Associated Press, April 30 2013. [http://www.cbc. $\mathrm{ca} /$ news/health/story/2013/04/30/windpipestem-cells.html.]

29. Stem cell agency approves plan for clinical trial network. Los Angeles Times, July 262013. [http://www.latimes.com/news/science/sciencenow/la-sci-sn-stem-cell-clinic-networkcirm-20130726.0.6547528.story.]

30. Maryland Stem Cell Research Commission funds 31 new research proposals in FY2013. PR Newswire, May 21 2013. [http://www.prnewswire.com/news-releases/maryland-stem-cellresearch-commission-funds-31-new-researchproposals-in-fy-2013-208293131.html.]

31. Kaiser J. Texas's Cancer Fund lures leading stem cell researcher. Science, May 13 2011. [http:// news.sciencemag.org/2011/05/texass-cancerfund-lures-leading-stem-cell-researcher.]

32. Kansas panel approves plan to fund stem cell center. KAKE TV, May 9 2013. [http://www. kake.com/home/headlines/Kansas-PanelApproves-Plan-To-Fund-Stem-Cell-Center-206853481.html.] [http://www.sfgate.com/ news/article/Kan-panel-approves-plan-tofund-stem-cell-center-4503798.php.]
33. Voorhees S. URMC opens stem cell facility. Your News Now (YNN), December 202012. [http://Rochester.ynn.com/content/top_stories/621174/urmc-opens-stem-cell-facility/.]

34. San Diego, CA to host World Stem Cell Summit December 4-6, 2013. Co-organizers of largest Interdisciplinary Stem Cell Meeting include: Genetics Policy Institute, California Institute for Regenerative Medicine, Mayo Clinic, The Scripps Research Institute and Sanford-Burnham Medical Research Institute. Genetics Policy Institute Press Release, April 16 2013. [http://www.online. wsj.com/article/PR-CO-20130416-907467. html?mod=googlenews_wsj.]

35. Lindsay D. Former BioMalta Head's Welsh dealings being investigated. Business Weekly, October 3 2013. [http://www.independent. com.mt/articles/2013-10-03/news/former-biomalta-heads-welsh-dealings-being-investigated-2786951170/.]

36. Camilleri I. Former BioMalta Head's Welsh dealings being investigated. Business Weekly, October 3 2013. [http://www. timesofmalta.com/articles/view/20131003/ local/Science-guru-I-want-Muscat-toapologise.488695\#5bFNdzZg.]

37. Carmichael J. Seabee donates stem cells to save a life. Navy News, August 7 2013. [http://www. military.com/daily-news/2013/08/07/seabeedonates-stem-cells-to-save-a-life.html?comp= 7000023468025\&rank=2.]

38. Androsko D. Robin Roberts returns to GMA. Use of adult stem cells to treat her blood disorder overlooked. National Right to Life News, February 21 2013. [http:// www.nationalrighttolifenews.org/news/2013/02/robin-roberts-returns-to-gma-use-of-adult-stem-cells-to-treather-blood-disorder-overlooked/\#.USdUTh3TyFs.]

39. Tanimoto T, Uchida N, Kodama Y, Teshima T, Taniguchi S. Safety of workers at the Fukushima Daiichi nuclear power plant. Lancet. 2011: 377(9776); 1489-1490.

40. Blackburn-Starza A. Back up your stem cells for $\$ 40,000$. BioNews, September 162013. [http://www. bionews.org.uk.page_34227.asp.] 
41. Certified Mail from FDA to Regenerative Sciences, Inc., July 25 2008. [http://www.fda.gov/ Biologics BloodVaccines/GuidanceComplianceRegulatoryInformation/ComplianceActivities/Enforcement/UntitledLetters/ucm091991. htm\#.UfUZa8wvEy0.email.]

42. Kaiser J. US Federal Court says stem cell treatments are drugs. Science, July 26 2012. [http:// news.sciencemag.org/2012/07/u.s.-federalcourt-says-stem-cell-treatments-are-drugs.]
43. Wong X, Chan L. China to further regulate stem cell clinical experiments. People Daily|Xinhua, March 8 2013. [http://English.peopledaily.com. cn/202936/ 8158848.html.]

44. Philips D. Orange County woman meets her stem cell donor for 1st time. KABC-TV Los Angeles News, August 17 2013. [http://abclocal.go.com/kabc/story?section=news/local/orange_county\&id=9209966.] 